\title{
EFFECT OF SOYA BEAN DIET PREPARATIONS ON SOME HAEMATOLOGICAL AND BIOCHEMICAL INDICES IN THE RAT
}

\author{
ALADA* A.R.A, AKANDE O. O. AND AJAYT F.F \\ Department of Physiology, College of Medicine, University of Ibadan, Ibadan-Nigeria.
}

\begin{abstract}
Effects of Soya bean diet preparations on the hematocrit, hemoglobin concentration, total plasma protein, plasma albumin, sodium, potassium and chloride concentrations were studied in male albino rats. The animals were fed diets containing $75 \%, 50 \%$ and $25 \%$ Soya bean in groups II, III and IV respectively. Group I rats served as the control and were fed normal mouse cubes. There were steady but significant increases in the concentrations of hematocrit, hemoglobin, total plasma protein and plasma albumin in rats fed $25 \%$ to $75 \%$ concentration of Soya bean in the diets. Although there were significant increases in the electrolytes concentrations between the Soya bean diets and rats fed normal diet, there was no significant difference in the electrolytes concentrations of rats fed different concentrations of Soya bean. This study therefore seems to confirm the nutritional value of Soya bean in alleviating malnutrition.
\end{abstract}

${ }^{*}$ Correspondence author

\section{INTRODUCTION}

Increased reliance on vegetable protein has become a major factor in preventing worldwide malnutrition and hunger (Hardinge, 1966). Soya bean (Glycin max.) is a widely used, inexpensive, and nutritional source of dietary protein (McArthur et al; 1988). Its protein content $(40 \%)$ is higher and more economical than that of beef $(18 \%)$, chicken $(20 \%)$, fish $(18 \%)$ and groundnut (23\%) (IITA, 1990). Soya bean is also of particular interest as a vegetable protein source because of its cholesterol lowering abilities in patients with type II hyperlipoproteinamia (Sirtori et al; 1985, Lovati et al; 2000). Apart from proteins, Soya beans also contain carbohydrate $(32 \%)$, fat $(20 \%)$, minerals/vitamins $(5 \%)$ and fiber (3\%).

A lot of work has been reported in the literature on the chemical composition, cultivation and processing of Soya bean (Mattil, 1974). However, more studies need to be carried out to elucidate its nutritional value. Recently, the report of Olaleye et a!; (1999) showed that raw soy bean reduced red cell osmotic fragility and could also reduce the hematocrit in the rat depending on the processing methods applied. The presence of trypsin inhibitor in soy protein was ascribed to be responsible for these effects. More recently, we also reported that Soya bean has a buffering effect on gastric acidity and ameliorates induced ulcers (Alada et al; 2004).In the study, the high protein content of Soya bean was implicated as being responsible for its effect.

Although, several studies (Alada, 2000, Bolarinwa et al; 1991, McArthur et al; 1988) have shown the relative importance of some animal and vegetable protein diets in the formation and composition of blood, there is little information except the report of Olaleye et al; (1999) on the effect of Soya bean on the hematological indices in the rat. In view of the increasing use of Soya bean as a major source of protein in several communities, there is a need to revisit its effect on some hematological and 
biochemical parameters with a view to ascertain the quantity of Soya bean in the diet that can have deleterious effect on the body systems. The present study was therefore designed to investigate the effects of different (in quantity) Soya bean diet preparations on some hematological and biochemical indices in the rat.

\section{MATERIALS AND METHODS}

The study was carried out on fasted male albino rats (250-300gm).

\section{Preparation of Soya bean Diet}

Soya bean diet was prepared according to the method of Bolarinwa et al; (1991) as shown in table 1 . The ingredients were mixed with water in adequate proportion, molded in lumps and cubes and dried in an electric oven at a controlled temperature of about $50^{\circ} \mathrm{C}$. When dried, the feeds were properly stored to avoid contamination from pests and moulds. In order to avoid degradation of its constituents, the diet was prepared once every week throughout the study.

The control rats were fed normal mouse cubes prepared by Ladokun Feeds Limited, Nigeria and are composed of protein $(21 \%)$, fat $(3.5 \%)$, fiber $(6 \%)$, calcium $(0.8 \%)$, and phosphorus $(0.8 \%)$.

\section{Experimental Procedure}

The experiments were carried out on four groups of rats with 8 rats per group. Rats in group 1 were fed with normal mouse cubes for six weeks and served as the control. Rats in group II were fed on a diet containing $75 \%$ Soya bean for six weeks. Rats in group III were fed with a diet containing $50 \%$ Soya bean for six weeks. Group IV rats were fed a diet containing $25 \%$ Soya bean for six weeks. At the end of the feeding period, blood samples were obtained from the tails of the animals for the determination of blood parameters such as Packed Cell Volume (PCV), Hemoglobin, Plasma Albumin, Total Plasma Protein, Plasma sodium, Plasma Potassium and Plasma Chloride. The PCV was measured by the microhematocrit centrifuge and spinning for $5 \mathrm{~mm}$. at $12,000 \mathrm{Xg}$ before reading with the hematocrit reader. Hemoglobin levels were measured by the cyanmethaemoglobin method using a CE404 colorimeter (Cecil Instruments). Plasma Albumin and Total Plasma Protein were determined by using Bromo-Gresol green method and Buiret method respectively. Plasma sodium and potassium concentrations were determined using flame photometry, while the plasma chloride level was measured by using mercuric nitrite method of Schales and Schales (1941).

\section{Statistical Analysis}

Results were expressed as mean \pm S.E.M. The significance of difference between means was determined by Student's-test and the results were regarded as significant at $\mathrm{P} 0.05$.

\section{RESULTS}

The results of the effects of Soya bean diet preparation on hematocrit, hemoglobin concentration, plasma albumin, total plasma protein, plasma concentrations of sodium, potassium and chloride are shown in table 2. Consumption of the Soya bean diet preparations by the rats caused gradual but significant increases in the hematocrit as the concentration of the Soya bean in the diet is increased. That is, the higher the concentration of the bean in the preparation, the greater the hematocrit. Soya bean also caused significant increases $(P<0.01)$ in the hemoglobin concentrations at the different concentrations of the Soya bean diets. There was however, no significant difference in the hemoglobin concentrations of rats fed different concentrations of Soya bean.

\section{Table 1:}

Composition in percentages of different preparations of Soya Bean Diets

\begin{tabular}{|c|c|c|c|}
\hline Ingredients & $\begin{array}{l}75 \% \\
\text { Soybean }\end{array}$ & $\begin{array}{l}50 \% \\
\text { Soybean }\end{array}$ & $\begin{array}{l}25 \% \\
\text { Soybean }\end{array}$ \\
\hline Maize & 11.0 & 36.0 & 61.0 \\
\hline Rice grain & 3.0 & 3.0 & 3.0 \\
\hline $\begin{array}{l}\text { Groundnut } \\
\text { oil }\end{array}$ & 5.0 & 5.0 & 5.0 \\
\hline Minerals & 4.0 & 4.0 & 4.0 \\
\hline Vitamins & 2.0 & 2.0 & 2.0 \\
\hline $\begin{array}{l}\text { Soybean } \\
\text { meal }\end{array}$ & 75.0 & 50.0 & 25.0 \\
\hline
\end{tabular}


Although, Soya bean diets produced significant increases in the total plasma protein especially at $50 \%$ and $75 \%$ concentrations, it only produced a slight but significant increase $(\mathrm{P}<0.05)$ in plasma albumin at $75 \%$ Soya bean concentration. In other words, there is no significant difference in the plasma albumin levels at $25 \%$ and $50 \%$ Soya bean concentrations compared with the controls.

The different preparations of Soya bean diet produced significant increases in the plasma concentrations of sodium, potassium and chloride. However, increasing the concentrations of Soya bean in the diets did not produce any significant difference in the electrolytes levels of the three Soya bean diet fed groups.

Table 2:

Effects of Soya bean diet preparations on some hematological and Biochemical indices. Values are expressed as mean \pm S.E.M. ${ }^{*} \mathrm{P}<0.05$, ** $0.01,{ }^{* * *} 0.001$

\begin{tabular}{|c|c|c|c|}
\hline $\begin{array}{l}\text { Hematological/ } \\
\text { Biochemical } \\
\text { Parameters. }\end{array}$ & $\begin{array}{l}\text { Normal } \\
\text { Diet } \\
\text { (Control) }\end{array}$ & $\begin{array}{l}25 \% \\
\text { Soya } \\
\text { bean } \\
\text { Diet }\end{array}$ & $\begin{array}{l}50 \% \\
\text { Soya } \\
\text { bean } \\
\text { Diet }\end{array}$ \\
\hline $\begin{array}{ll}\text { Total Plasma } \\
\text { Protein }(\mathrm{gm} / \mathrm{l})\end{array}$ & $\begin{array}{l}6.3 \\
\pm 0.27 \\
\end{array}$ & $\begin{array}{l}6.6 \\
\pm 0.10 \\
\end{array}$ & $\begin{array}{l}6.9 \\
\pm 0.10^{* *} \\
\end{array}$ \\
\hline $\begin{array}{l}\text { Plasma } \\
\text { Albumin }(\mathrm{gm} / \mathrm{l})\end{array}$ & $\begin{array}{l}4.6 \\
\pm 0.24 \\
\end{array}$ & $\begin{array}{l}4.5 \\
\pm 0.04\end{array}$ & $\begin{array}{l}4.7 \\
\pm 0.13\end{array}$ \\
\hline $\begin{array}{l}\text { Hemoglobin } \\
(\mathrm{gm} / \mathrm{l})\end{array}$ & $\begin{array}{l}12.0 \\
\pm 0.04 \\
\end{array}$ & $\begin{array}{l}14.2 \\
\pm 0.20^{* *} \\
\end{array}$ & $\begin{array}{l}14.1 \\
\pm 0.20^{* *} \\
\end{array}$ \\
\hline $\begin{array}{l}\text { Hematocrit } \\
(\mathrm{gm} \%)\end{array}$ & $\begin{array}{l}42.0 \\
\pm 0.58 \\
\end{array}$ & $\begin{array}{l}43.0 \\
\pm 0.54 \\
\end{array}$ & $\begin{array}{l}44.0 \\
\pm 044^{*} \\
\end{array}$ \\
\hline $\mathrm{Na}^{+}($meq/l) & $\begin{array}{l}149.0 \\
\pm 0.84 \\
\end{array}$ & $\begin{array}{l}153.0 \\
\pm 2.57 \\
\end{array}$ & $\begin{array}{l}174.0 \\
\pm 3.20^{\star \star *}\end{array}$ \\
\hline $\mathrm{K}^{+}(\mathrm{meq} / \mathrm{l})$ & $\begin{array}{l}6.5 \\
\pm 0.10 \\
\end{array}$ & $\begin{array}{l}32.0 \\
\pm 0.81^{* * *}\end{array}$ & $\begin{array}{l}36.0 \\
\pm 0.77^{* \star *}\end{array}$ \\
\hline $\mathrm{Cl}^{-}$(meq/) & $\begin{array}{r}106.0 \\
\pm 0.85 \\
\end{array}$ & $\begin{array}{l}127.0 \\
\pm 0.81^{* *} \\
\end{array}$ & $\begin{array}{l}134.0 \\
\pm 0.67^{\star *} \\
\end{array}$ \\
\hline
\end{tabular}

\section{DISCUSSION}

The significant increases in the total plasma protein and plasma albumin levels observed in rats fed soyabean diet preparations as compared with those fed normal rat diet in this study is consistent with the report of Bolarinwa et al; (1991), in which there was a significant reduction in the levels of total plasma protein and plasma albumin in protein-calorie malnourished rats. Hegsted (1968) and Laditan (1976) had earlier drawn a correlation between plasma protein levels and severity of protein malnutrition. The protein content of soyabean is quite high ranging from $40 \%$ in full fat sunflower to $90 \%$ in isolate (IITA, 1990) and could be responsible for the high levels of the total plasma protein and plasma albumin. Indeed, the protein content of soybean is considerably higher than that of meat, fish, egg and other diary products (McArthur et a!; 1988).

The increases in the plasma sodium, potassium and chloride concentrations in the rat fed soybean diet compared with rats on normal diet in this study are probably as a result of high concentration of these electrolytes in soybean (IITA, 1990). For instance, soyabean contains $1.6 \%$ potassium, $21 \%$ sodium and $0.8 \%$ chloride. In addition, with the increasing level of soyabean in the soybean diet preparations in the present study, the potassium content 75्tor becomes higher. Mitchell et al (1976) $75 \%$ observed that more potassium is beânded for the metabolism of high protein Dfiet. The results of the present study 8.heretore seem to support this observation. $\pm 0.20^{\text {*kne }}$ observed increases in the 4 !remoglobin concentrations and hematocrit \pm le.vels in rats fed on different concentrations 10.2 soybean diet preparations in this study is \pm cohsotstent with earlier reports on the 48 orrelation between hematocrit and dietary \pm pr:aleins. However, this observation is 1 es Ptrary to the results of Olaleye et al, $\left.\pm 2.599_{9}^{* *}\right)$ which showed either a decrease or 42 . 0 effect on the hematocrit and hemoglobin 1 fơndeentrations of rats fed differently pr.ggensed Soya bean diets. One fundamental difference in the present study and that of Olaleye et al (1999) is the methods of preparation of the Soya bean diets. While the present study has used only raw Soya bean which was oven-dried at regulated temperature, the report of Olaleye et al (1999) used sun-dried raw Soya bean, boiled Soya bean, roasted soya bean and alkali treated Soya bean diets. The difference in the results of the present study and that of Olaleye et al; (1999) could 
therefore be due to the differences in the preparations of the Soya bean diets.

Several protein-rich diets have been shown to increase both hematocrit levels and hemoglobin concentrations in human and animal studies (Bolarinwa et al; 1991, Mitchell, 1966). Indeed, animals fed proteincalorie malnourish diets have been reported to have significant reduction in hematocrit and hemoglobin concentrations (Bolarinwa et al; 1991). Again, it is well-documented that kwashiorkor and marasmus patients have low levels of hematological indices (Mitchell, 1966, Adesola, 1968, Coward and Whitehead, 1972). Apart from the high quantity of protein in soybean, the protein is also of high quality, consisting of most of the essential amino acids (IITA, 1990). Soybean is also rich in minerals and vitamins such as iron, zinc, copper, thiamine, riboflavin, niacin and patholenic acid (McArthur et al; 988). Most of these minerals and vitamins are well-known hematinics and are essential in the formation of red blood cells (Ganong, 1993, Mitchell et a!; 1976).

\section{REFERENCES}

Adesola A.L (1968). The influence of severe protein deficiency (kwashiorkor) on gastric acid secretion in Nigerian children. Brit. J. Surg. 55: 866.

Alada A.R.A. (2000): The hematological effect of Telfaria occidentalis diet preparations in the rat. Afr. J. Biomed. Res. 3: 185-186.

Alada A.R.A, Ajayi F.F, Alaka $\mathbf{0 . O}$ and Akande 0.0 (2004): Effects of Soybean diet preparations on acid secretion and experimental ulceration in the rat. Afr. J. Med. med. Sci. (In press).

Bolarinwa A.F, Oyebola D.D.O and Akindeinde G.B (1991): Effect of malnutrition on basal and induced gastric acid secretion. Nig. J. Physiol. Sci.; 5(2): 144-148.
Coward W.A and Whitehead R.G (1972): Changes in hemoglobin concentrations during the development of kwashiorkor. Brit. J. Nutr. 28: 468-469.

Gannong W.F (1993): Review of Medical Physiology. 16 edition, Appleton and Lange. pp 469.

Hardinge M.G(1966): Nutritional studies on vegetarians. J. Am. Diet. A. 48:

25- 30.

Hegsted D.M (1968). Amino acid fortification and protein problem. Am. J. Clin. Nutr. 21: 688- 692. International Institute of Tropical Agriculture (11TA)) (1990): Soybean for good health, IITA, Ibadan, Nigeria.

Laditan A.A (1976): Some clinical data of prognostic importance in protein calorie malnutrition (pcm). Trop. Geogr. Med. 28 (3):

216- 219.

Lovati M.R, Manzom C, Gianazza B, Arnoldi A, Kurowska E, Carroll K.K, Sirtori C.R (2000): Soy protein peptides regulate cholesterol homeostasis in Hep G2 cells. J. of Nutr. 130: 2543- 2549.

McArthur K.E. Walsh J.H. and Richardson C.T. (1988): Soy protein meal- stimulates less gastric acid secretion and gastrin release than beef meal. Scan. J. Gastroint. 95: 920-926.

Mitchell H.S (1966): Protein limitation and human growth. J. Am. Diet. A. 44: 165- 171.

Mitchell H.S, Rynbergen H.J, Anderson L and Dibble M.V (1976): Nutrition in health and disease. 16 Ed.J.B Lippincott Company, Philadelphia.

Olaleye S.B, Iranloye B.O, Salami H.A and Elegbe R.A (1999): Erythrocyte osmotic fragility and other blood parameters in rats fed with diets containing raw and processed soyabeans (Glycine max). Biosci Res. Comm. 11(2): 107 112.

Schales H and Schales C (1941): Simple and accurate method for determination of chloride in biological fluids. J. Biol. Chem. 140: 879-884.

Sirtori C.R, Zucchi-Dentone C, Sirtori M, Gatti E, Descovich G.C, Gaddi A, Cattin L, Da Col P.G, Senin U, Mannarino C, et al (1985). Cholesterol lowering and HDL- raising properties of lecithinated soy protein in type II hyperlipidemic patients. Ann. Nutr. Metab. 29 (6): 348- 357. 